\title{
Just one of the 'PIIGS' or a European outlier? Studying Irish emigration from a comparative perspective
}

\author{
IRIAL GLYNN \\ Leiden University, Institute for History, Doelensteeg 16 Leiden 2311 \\ VL, Netherlands
}

\begin{abstract}
The return of high levels of emigration has become one of the most debated and sensitive social topics in Ireland in recent years. But Irish emigration continues to be discussed in the singular rather than the plural. This paper compares Irish emigration to other Eurozone states that also encountered serious economic difficulties following the onset of the global financial crisis to highlight international trends and specify national differences. All of the 'PIIGS' experienced increased emigration after the crisis. Yet Irish citizens left in much greater numbers per capita than their Eurozone counterparts, with only Portugal bearing any similarities. This was because Irish emigrants possessed valuable transnational human, cultural and social capital that enabled them to access liberal labour markets outside the Eurozone. They possessed skills desired by attractive destination states; they spoke the same language and shared similar cultural traits as their hosts; and they were able to call upon recently renewed Irish networks to further facilitate their move abroad.
\end{abstract}

Keywords: emigration, Ireland, transnational capital, crisis, intra-EU mobility

\section{Introduction}

Emigration was not unique to Ireland. But the type of emigration, the scale of emigration and the impact of emigration were. (Lee 1989)

[...]Irish exceptionalism has been too long an unexamined doctrine. Actually, much of what happened in Ireland occurred elsewhere in Europe as well, and most of the things that Irish migrants did were done by other Europeans also. (Akenson 2011)

The Irish migration experience has been studied mostly in the singular rather than the plural. This is a pity because, as Brettell and Hollifield (2000: 14) have surmised, comparative works have provided some of the most 'important and pathbreaking work on migration' so far produced. Several historians have contrasted 
Irish emigrants' experiences in different locations (Akenson 1996; Campbell 2008), but few have compared the Irish case with that of others. The limited numbers of historical works that do exist tend to be confined to examinations of nineteenth and early twentieth century emigration (Hatton and Williamson 1998; Diner 2002; Akenson 2011; Glynn 2011; Belchem 2011), rather than studies of more recent trends. In the post-war decades, Ireland was not the only country to see large swathes of its population emigrate. Yet, scholars have infrequently attempted to place Ireland in a European perspective, with Delaney (2000) offering a rare exception. It is important to note that this exclusivity is not merely a trait of scholars examining Irish emigration. The literature on international migration rarely includes Ireland or the Irish in analyses. Indeed, Ryan (2013) has written of her frustration at 'the lack of reference to Irish research in studies of other migrant groups, when comparisons seem quite obvious'. This paper seeks to go beyond the confines of analysing just one case by comparing Irish emigration since 2008 to that of four other Western European countries. Kocka (2003: 40) notes that 'comparison does not only help to support notions of particularity, but is also indispensable for challenging and modifying such notions'. With this in mind, this paper seeks to determine whether Ireland was just one of the 'PIIGS'1 (Portugal, Ireland, Italy, Greece and Spain) or a European emigration outlier.

To help resolve such a puzzle, the context for why emigration increased in recent years from all five countries will first be set. Subsequently, the paper will demonstrate that Irish emigration was substantially different in terms of its scale and character when compared to Italian, Spanish, Greek, and, to a lesser extent, Portuguese emigration. The main explanation advanced for this difference was that Irish emigrants possessed valuable transnational human, cultural and social capital that enabled them to move to English-speaking liberal labour markets that came through the crisis more rapidly than Eurozone states. Transnational capital is understood here to mean the 'intercultural competence' that allowed migrants to 'operate in different fields beyond the individual nation-state' (Gerhards and Hans 2013: 99-100). Human capital is 'an individual's labour power, skills, training and abilities' (Piketty 2014: 46). Cultural capital is more difficult to define. Bourdieu (1986) first used the concept to 'explain the unequal scholastic achievement of children originating from the different social classes'. Several authors have since applied Bourdieu's theory to the difficulties encountered by immigrants in their adopted homes. For instance, Bauder (2003: 699) argues that 'the nonrecognition of foreign credentials amounts to the systematic exclusion of immigrant workers from the upper segments of the labour market'. It is argued in this paper, however, that Irish emigrants were able to bypass these types of constraints and thereby 'participate in locally-shared professional cultures' (Erel 2010: 648) because their cultural capital resembled that of their host societies. Social capital refers to the ability to benefit from certain networks. Portes (1998: 7) eloquently sums it up as follows: 'Whereas economic capital is in people's bank 
accounts and human capital is inside their heads, social capital inheres in the structure of their relationships. To possess social capital, a person must be related to others, and it is those others, not himself, who are the actual source of his or her advantage'.

Irish emigrants' skills, cultural background and social networks enabled them to take full advantage of migration agreements with Australia, New Zealand and Canada when the economic crisis hit. They were also able to profit from the improving economic situation in the UK. Their qualifications were recognised because they spoke the same language and shared many cultural and historical similarities with their hosts, which enabled Irish newcomers to avoid some of the obvious boundaries protecting natives and compete with them in the labour market on a relatively level playing field. Prospective Greek, Portuguese, Spanish or Italian migrants did not have the same options because migration agreements between southern European states and these traditional settler-states remain in their infancy. Although Portuguese, Spanish and Italian citizens shared cultural ties with Latin America, that continent did not offer the same economic opportunities as the English-speaking states targeted by Irish emigrants. Certain Portuguese-speaking African countries undergoing enormous growth and expansion, by contrast, did attract sizeable skilled Portuguese emigration. This partly explains why the scale of Portuguese emigration corresponds most closely to Irish emigration. Another potential explanation to further explain why citizens from these two countries emigrated in greater numbers, explored in further detail towards the end of the paper, is that Irish and Portuguese citizens could call upon vibrant social networks of co-nationals, which had been revitalised in the years preceding the crisis, to help them settle abroad.

It is important to note that this article focuses predominantly on the emigration of Irish, Portuguese, Italian, Greek and Spanish citizens rather than immigrants moving away from the 'PIIGS'. The emigration of a country's own citizens is the main reason the topic has once again become an issue of public and political concern in Ireland and elsewhere. Citizens usually have strong ties with the communities and families they leave behind and the state has invested significantly in these people's education. By contrast, when immigrants leave the 'PIIGS' to return home or move on to another country it does not usually provoke the same outcry from the public.

\section{Setting the context}

The global financial crisis, variously referred to by leading economists as the 'Great Recession' (Stiglitz 2010: xi) or the 'Lesser Depression' (Krugman 2011), had an enormous impact on the Eurozone and Ireland after 2008. According to Donovan and Murphy (2013: 255), 'Few, if any industrial countries have succumbed so quickly and so sharply to a financial crisis' as Ireland. Real Irish GDP fell by 3 per cent in 2008 and 7 per cent in 2009. The Irish banking system almost 
disintegrated and only survived because of a controversial state guarantee. In 2010, Ireland's budget deficit rose to an incredible 31 per cent of GDP. As a consequence of the state's economic turmoil, the Irish debt to GDP ratio quadrupled (Ibid.: 2). A national bailout from the 'Troika' (consisting of the IMF, the European Commission and the European Central Bank) followed in late 2011. In response to the serious economic difficulties Ireland faced, the Irish government took a number of austerity measures. It introduced a recruitment and promotion moratorium for the civil service, local authorities, non-commercial state bodies, the police and the defence forces (RTÉ 2009). A modified version applied to the health and education sectors. The ensuing 'Croke Park Agreement' between the unions and the state led to sizeable early retirements taking place and little or no hiring of replacements. Civil servants in employment saw their wages decrease significantly.

Between 2007 and 2012, unemployment trebled, from under five per cent to over fifteen per cent. Youth unemployment also saw a marked increase. During the same time period, national housing prices decreased by approximately fifty per cent (Lyons 2015). Certain labour sectors felt the brunt of the recession more profoundly than others. The demise of the construction industry had a major impact on unemployment figures, particularly for males. The amount of people working in the industry dropped from a peak of 380,000 to approximately 150,000 by the end of 2011 (Society of Chartered Surveyors Ireland 2012: 6). The crisis also caused a notable downturn in employment in manufacturing and retail, as consumer spending decreased across Ireland and its export markets. Rising unemployment, a distinct lack of job opportunities for graduates and the recently unemployed, as well as reduced wages and limited openings for promotion for those with jobs resulted in a significant rise in emigration. Yet, Ireland was not the only Eurozone country faced with near economic meltdown.

Greece preceded Ireland by entering into its first bailout with the IMF and the Eurozone countries in May 2010. A second bailout with the Troika followed less than two years later. The Greek economy declined by an astounding twenty-three per cent between 2007 and 2013. Matsaganis and Leventi (2014: 408), in a paper comparing the effects of austerity and recession on Greece, Portugal, Italy and Spain, concluded that Greece has felt the effects of the crisis most starkly, with poverty and inequality rising to 'alarming levels'. Portugal too required its own bailouts from the Troika in May 2011. In a similar fashion to what occurred in Ireland, taxes rose, while unemployment benefit, family allowances, social assistance and public sector wages decreased (Leahy, Healy and Murphy 2013: 33). The Spanish case resembles what occurred in Ireland most closely. Between 1995 and 2007, the number of people employed in construction in Spain increased from 1.2 million to 2.8 million (Meardi, Martín and Riera 2012: 10). Replicating the Irish experience, the economic crisis heralded the demise of the previously booming Spanish construction industry. A banking crisis followed. In contrast to 
Ireland, banks moved quickly to repossess properties in Spain. In the first six months of 2012 alone, banks repossessed almost 100,000 properties whereas repossessions remained minimal in Ireland (Fuentes et al. 2013: 1198). The crisis did not affect Italy as dramatically as the other 'PIIGS', partly because it had followed many years of stagnation rather than any enormous growth. Nevertheless, the crisis added to the country's woes. Following the rise of Spanish and Italian bond yields to unsustainable levels in the summer of 2012, the European Central Bank established its long-term refinancing operation (LTRO) - unlike the other countries, Italy and Spain were too big to bail out - and pledged to purchase unlimited sovereign debt to ensure the survival of the Euro. The Italian and Spanish governments instigated further austerity measures as a result, which bore many similarities to what happened in Ireland (e.g. cutbacks in education and health expenditure, public sector salary reductions and limited public recruitment). The most glaring evidence of the consequences of the crisis manifested itself in national unemployment statistics.

Spanish and Greek unemployment more than trebled between 2007 and 2013, from eight per cent to twenty-six per cent. Portuguese and Italian unemployment rose substantially - but not quite as dramatically (see Figure 1).

Rocketing youth unemployment became an enormous problem in the 'PIIGS', particularly in Spain and Greece, where over fifty-five per cent of 15-24 year olds in the labour force were without work by 2013. Considering the enormity of Spanish and Greek unemployment, especially when compared to Ireland's, it might have been expected that these countries experienced higher levels of emigration. Yet, the reality proved quite different.

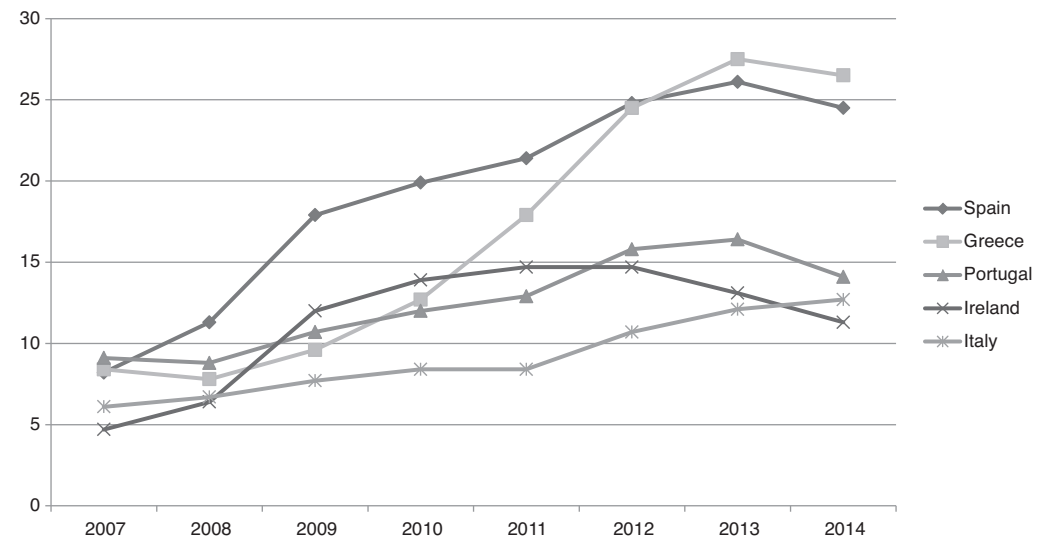

Figure 1 Unemployment in the 'PIIGS', 2007-14 (in per cent).

Source: Eurostat 


\section{Comparing scales}

In response to the effects of the crisis, emigration from the 'PIIGS' re-emerged as an issue in national debates. It is extremely important to remember that emigration is not just a result of unemployment and underemployment. A recent analysis of Irish emigration revealed that different people leave for divergent reasons. Almost half of those emigrating possessed full-time jobs prior to their departure. A sizeable proportion of these people left because they wanted to travel and experience other cultures. These were often people with qualifications that other countries coveted, such as valuable IT skills or health professionals (Glynn, Kelly and Mac Éinrí 2013: 38). Dissatisfaction with people's career prospects caused others to leave. Many emigrants reported being unhappy with their long-term career prospects in Ireland before departure. Those in employment before emigrating (including those working part-time), gave an average score of 5.5 out of 10 for their job satisfaction in Ireland compared to 7.6 out of 10 for Irish emigrants' job satisfaction abroad - a notable improvement (Ibid.: 66). Certain people working in jobs unrelated to their qualifications felt that going abroad might enable them to put into practice the skills that they had acquired over the preceding years. Others felt that they had few opportunities to develop their career at home due to the knockon effects of the crisis. People's contract status also sometimes played a role. Those with short-term and temporary contracts faced an uncertain future. Some attempted to take back the initiative by emigrating.

For Irish people made redundant during the crisis, the prospects of finding work again in such a depressed and competitive economic environment also caused many to look overseas. Over one third of Irish emigrants were either unemployed (twenty-three per cent) or underemployed (thirteen per cent) when they left. Students who graduated in the years hardest hit by the recession struggled to break into the job market. This was reflected in the fact that fifteen per cent of emigrants consisted of people who were previously students. Fewer graduate positions presented themselves and various students who emigrated after completion of their courses cited the unfair rivalry that they often faced from senior candidates when applying for junior positions. The state recruitment embargo also meant that school and university graduates hoping to work as police officers or teachers, for example, had limited options in Ireland. Similarly, many of those who aimed to work in the health sector, such as nurses, physiotherapists and occupational therapists, had few employment possibilities following graduation. A small number of people emigrated for a range of personal reasons, such as to join up with a partner based abroad or to study overseas.

The Irish Central Statistics Office (CSO) produces annual migration figures that provide a breakdown of the number of Irish people leaving and returning every year, based on sex, age, education and destination/origin. They also produce statistics for a range of other nationalities and regions (e.g. UK citizens, EU12 citizens). Researchers studying Irish emigration are lucky to have such a valuable source of 
information. The estimates take account of the number of UK National Insurance numbers and work permits granted to Irish citizens in various destinations, including Australia, the United States, Canada and New Zealand. The data clearly show that the number of Irish citizens leaving Ireland almost quadrupled between 2008 and 2013. In 2014, figures dropped somewhat - presumably as a result of more positive economic news in Ireland - but the number of Irish people returning also decreased, leaving one to wonder whether Irish emigrants are becoming more settled abroad. Between 2010 and 2014, almost 210,000 Irish citizens emigrated (CSO 2014). In the same time period, slightly over 85,000 returned, leaving a net migration loss of over 120,000 citizens in five years (see Figure 2).

Unfortunately, it remains difficult to compare the scale of outflow across the five countries under consideration due to the lack of equivalent statistics available. Spanish and Italian official estimates are based on the amount of citizens registering at foreign consulates. These statistics need to be treated with enormous care, however, because not all Spaniards and Italians register their presence with consulates abroad, partly because they may lose certain health benefits in their country of origin by doing so. It is important to note that Spanish and Italian estimates also contain sizeable proportions of people who were actually born outside Spain and Italy but either gained citizenship after immigrating to these countries or qualified for citizenship through their parents or grandparents. This explains why over 10,000 Spanish citizens registered with Spanish consulates in Ecuador in 2013, for instance. Most were born in Ecuador and migrated to Spain in the late 1990s and 2000s, naturalised whilst there, and have since returned home - often with their Spanish-born children (INE 2014: 11).

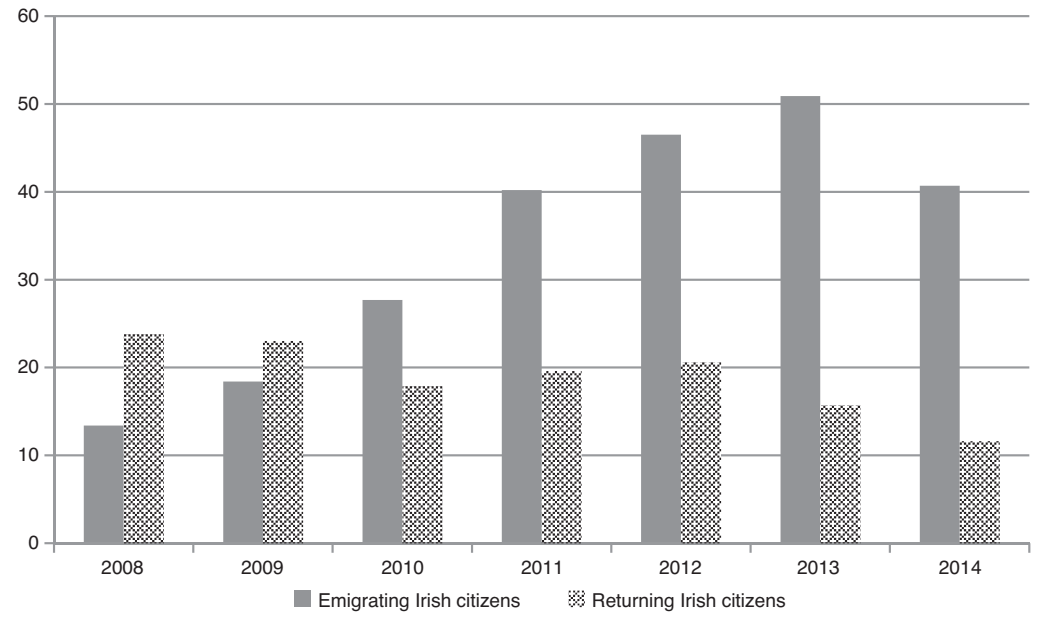

Figure 2 Migration of Irish citizens, 2008-14 (in 000s).

Source: CSO 2014 
Portuguese emigration statistics distinguish between different emigrants: one category comprises 'permanent' emigrants who leave for over one year and another category consists of 'temporary' emigrants who return within one year. The Portuguese INE (2014) notes that in 2009, less than 15,000 Portuguese citizens emigrated 'permanently'. In 2013, the corresponding figure had risen to over 50,000. Additionally, more than 70,000 Portuguese citizens emigrated 'temporarily' in 2013. This accounts for such movements as Portuguese workers' seasonal work in the Swiss tourist industry and temporary contracts in Angola, but the other 'PIIGS' do not differentiate between emigrants in this fashion, making it difficult to compare Portuguese figures. An academic research body, the Observatório da Emigração (2014: 36), has come up with its own annual emigration estimates based on destination data. They are slightly less than the combined temporary and permanent figures presented by the national statistics body, presumably because some temporary migrants can be counted by the state more than once if they fulfill several temporary contracts abroad in one year.

As outlined above, there are various problems with national statistics. Conversely, at least these estimates exist. No national official migration data is available for Greece apart from some Eurostat estimates. The limited Eurostat available does suggest that Greek emigration has increased considerably in recent years, but there is no national data to support this. Instead, researchers have to rely on census records that reveal the growth and decline of Greek citizens in different age cohorts. Yet, these only occur every ten years, with the last having taken place in May 2011.

Destination data can fill some of the gaps in our knowledge but they cannot provide a comprehensive picture because of a lack of consistency between states. France, a major target of Spanish, Portuguese, Italian and Greek emigrants in the post-war decades, for example, does not provide statistics comparable to some of its neighbouring countries. Nevertheless, some approximate trends can be identified from examining source statistics. Germany represents one of the most popular EU destinations for current European emigrants because of the relatively healthy state of its economy in recent years, especially when compared to other member states. Annual Greek emigration to Germany increased from under 9000 in 2009 to over 34,000 in 2012 (Statistisches Bundesamt 2014: 19). Spanish migrants followed a comparable trajectory, increasing from less than 10,000 in 2008 to over 36,000 by 2014. Similarly, less than 20,000 Italians arrived in 2009 but the number had almost trebled by 2013 . Unlike the late 1980s and early 1990s, Irish emigration to Germany has remained low in recent years, with English-speaking destinations preferred. Italian, Spanish and Portuguese emigrants have also moved to Switzerland, a non-EU country with particularly low unemployment rates. The presence of sizeable Spanish and, in particular, Italian and Portuguese communities in Switzerland meant that more recent emigrants could call upon those already in situ for assistance and advice. 


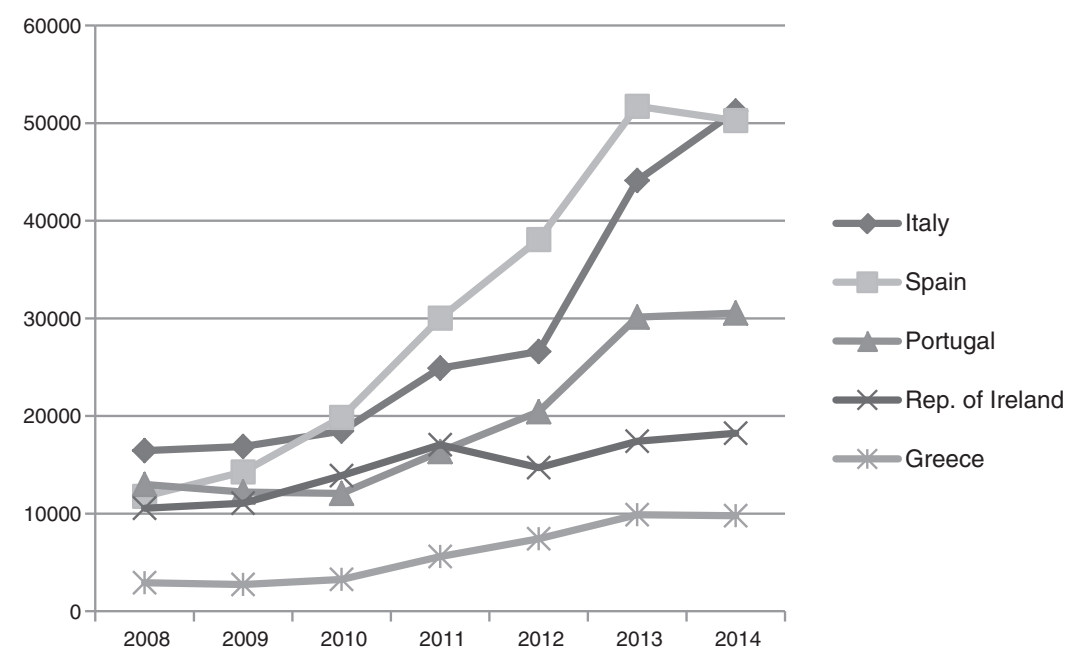

Figure 3 Acquisition of UK National Insurance Numbers by citizens from 'PIIGS', 2008-14.

Source: UK Department of Work and Pensions

Analogous patterns have emerged in the UK (see Figure 3). In 2013, over 50,000 Spaniards, almost 45,000 Italians and more than 30,000 Portuguese applied for UK National Insurance numbers. For the Spanish figures, this represented a more than three-fold increase since 2009. The number of new Italian and Portuguese arrivals seeking work in the UK also more than doubled during the same period. Irish figures, by contrast, did not rise so markedly, with slightly over 18,000 arriving in 2014 compared to just over 11,000 in 2009 . It is possible that some Irish emigrants may already have held national insurance numbers from previous time spent in the UK.

An analysis of the above chart may cause readers to speculate that there is nothing unique about Irish emigration. Yet, this masks a key feature of the current outflow: the emigrant per capita data. Italy and Spain's annual figures, although seemingly large in gross terms, are extremely low when compared to the size of their populations - almost 60 million and 47 million respectively. If the estimates provided by national statistical bodies for emigration in 2013 are compared, Ireland stands out amongst its Western European counterparts, particularly when set against Italy and Spain (see Figure 4).

As noted earlier, there is a notable difference between official Spanish and Italian emigration statistics and immigration figures provided by the UK and German authorities. For instance, over 100,000 Italian nationals and almost 90,000 Spanish nationals moved to Germany and the UK in 2013 according to destination statistics. Yet, the official Italian and Spanish estimates contend that less approximately 24,000 and 13,000 of their citizens respectively moved to 


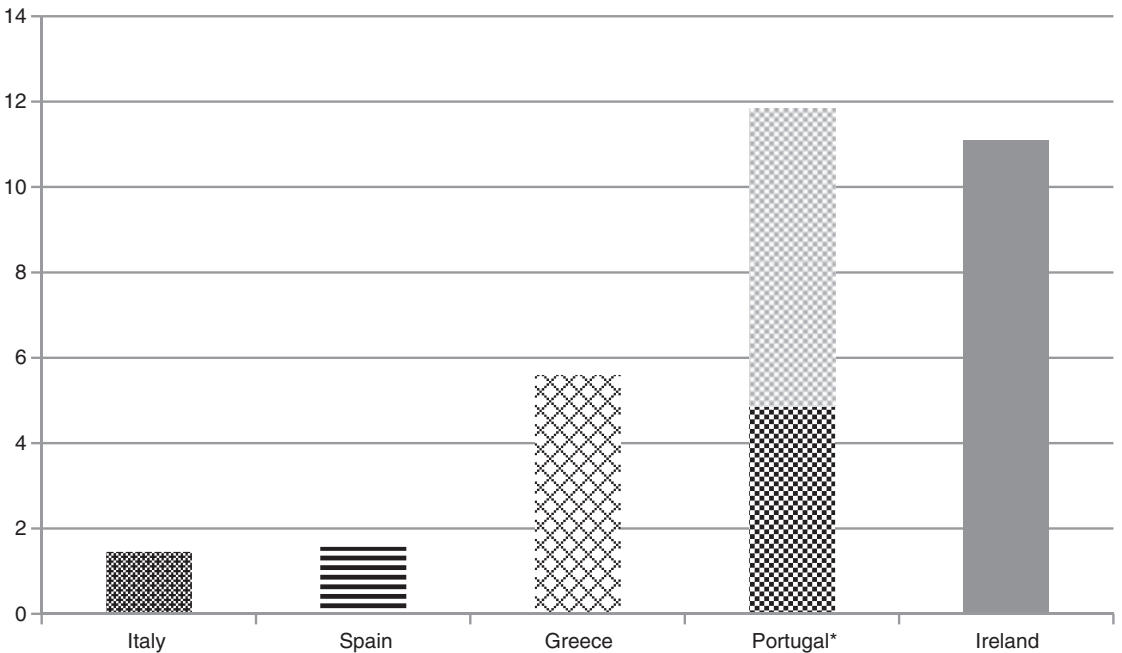

Figure 4 Gross emigration of Italian, Spanish, Greek, Portuguese and Irish citizens per 1,000 in 2013. Calculations based on CSO 2014, Eurostat (Table migr_emilctz), ISTAT 2014, INE 2014, INE Portugal 2014 (figures for 'permanent' emigration). *The light shaded part of the Portuguese bar reflects 'temporary' migration, as specified in INE Portugal 2014. Source: CSO 2014, Eurostat (Table migr_emi1ctz), ISTAT 2014, INE 2014 and INE Portugal 2014 data

these two countries in 2013. González-Ferrer (2013) has consequently argued that real Spanish emigration may be three times the size of official estimates. But even if Spanish and Italian emigration in 2013 is multiplied by three, it still pales in comparison to the departure of Irish, Greek and Portuguese citizens. Interestingly, the vast majority of people leaving Spain and Italy today are actually immigrants returning home or moving on to a third country. Large numbers of immigrants have also exited Greece as a result of the deteriorating economic conditions (OECD 2013: 256). Immigrants do feature in the emigration data in Ireland or Portugal, but not as prominently. Instead, it is citizens who have dominated recent outflows, particularly between 2011 and 2013 in Ireland's case. As occurred in the post-war emigration peaks (see figures contained in Münz 2007: 28), Ireland and Portugal have again experienced the greatest emigration per capita out of all the 'PIIGS', despite not having experienced the same level of unemployment as other states, such as Spain. Why is this? One key reason is because of the destinations that they can access due to the capital they possess.

\section{Transnational capital and desirable destinations}

Ireland has endured serious economic problems since 2008, as have Portugal, Italy, Greece and Spain. As a result, emigration has increased from all the 'PIIGS'. 
Yet, the scale of Irish emigration is unique compared to the other 'PIIGS'. The only country that comes close to replicating Ireland is Portugal - and this depends greatly on which statistics are used. The Irish could easily access the neighbouring UK, the most popular destination for emigrants in previous waves of emigration in the 1950s and 1980s (see Scully and Ryan in this issue), but they also had the advantage of being able to look beyond the confines of the EU for potential destinations. Indeed, the majority of Irish emigrants moved to non-EU countries, such as Australia and, more recently, Canada, which recovered from the effects of the crisis much quicker than European member states and consequently continued to welcome large numbers of newcomers as part of their organised immigration intake schemes that had been in place for decades. Irish citizens were targeted by these countries because of their valued transnational capital. Prospective Irish emigrants could enter Australia, New Zealand and Canada on working holiday migration schemes designed to attract young Irish citizens for one to two years. Emigrants had to be between 18 and 30 years of age to enter the Australian and New Zealand programmes, and between 18 and 35 for the Canada equivalent. Many managed to extend their stay through long-term skilled migration schemes because they had the qualifications and training that these countries desired. Their integration was further accelerated by the fact that they shared important historic and cultural links because British administration had featured so centrally in all of their pasts. Indeed, that common past ensured they spoke the same language. Furthermore, sizeable swathes of the Australian, Canadian and New Zealand population claimed Irish heritage due to historic emigration. Irish citizens were also able to take advantage of the presence of extensive Irish networks in these destination states, some of which had been replenished in the late 1990s and 2000s through lifestyle migration (Benson and O'Reilly 2009).

Australia and Canada emerged from the global financial crisis more rapidly than EU member states, partly because of the natural minerals available to them via their successful mining industries. The banking sectors in both countries also came through the downturn relatively unscathed. Irish emigrants took full advantage of the migrant schemes already in place between Ireland and Australia to emigrate there after the onset of the crisis. The working holiday visa scheme began in 1975 with reciprocal agreements between Australia and the UK, Ireland and Canada facilitating movement between the countries. Since the late 1990s, spending a year in Australia on the working holiday visa programme had become increasingly common for many young Irish people. This trend continued throughout the boom and in 2004 Australia extended its working holiday visa to two years for Irish citizens, provided they met certain conditions. Between 2002 and 2007, 11,000 to approximately 13,500 Irish travelled to Australia on the working holiday scheme each year (Gilmartin 2013: 11). New Zealand had a similar programme that accommodated young Irish people, although it did not attract the same kind of numbers of Irish as its Australian equivalent (approximately 2,000 per year). The expansion of Canada's working holiday visa 
programme and young professional programme enabled approximately 10,000 Irish to move there on two-year visas in 2014.

Apart from Italy, the other 'PIIGS' did not have the same access to these nonEU labour markets. Italy has shared a working holiday visa arrangement with Australia, akin to the Irish agreement, since 2004. The number of Italians attaining working holiday visas rose from less than 5000 in 2008/09 to over 16,000 in 2013/14 (Australian Department of Immigration and Citizenship 2014). However, in contrast to the Irish in Australia, only a small number of Italians transferred to Australia's skilled immigration programme during this period (as discussed further below). Despite Australia representing a popular destination for Greek emigrants in the post-war decades, the two countries only put in place a work and holiday agreement in May 2014. This type of scheme differed from the one available to young Irish and Italian citizens in that applicants had to speak functional English and were required to have completed at least two years of university education prior to arrival. Furthermore, the scheme lasted for one year only and could not be extended for another year. Spain signed a similar agreement in September 2014. Only 500 citizens from each state could benefit from the agreement per year, whereas no limits existed for Irish and Italian citizens.

An analogous story emerged for Canada. In 2015, the country offered 10,700 Irish citizens the opportunity to move across the Atlantic for two years under its various migration programmes instigated for young Irish workers. Only 1000 places were available for Italian and Spanish citizens to work in Canada - for one year instead of two. Greece fared even with worse, with only 200 places offered.

Portugal has yet to forge any agreement with Australia or Canada. Yet Portuguese emigrants had access to other important labour markets. Angola and Mozambique came through the crisis relatively unscathed, largely because of their mineral wealth. Having experienced annual growth of approximately seven to eight per cent in previous years, principally due to their vast wealth of natural resources, significant government reforms and the prospect of peace, stability and prosperity, they had much to offer certain Portuguese emigrants (Kvamme 2013). There is a demand in these two ex-Portuguese colonies for skilled professionals within the urban development and architecture sector, the mining and natural resource extraction industries and the growing medical industries. Most importantly, the countries share numerous cultural similarities as a result of Portugal's colonial history. Indeed, some Portuguese emigrants to Angola and Mozambique may be going back to the country of their birth or that of their parents. Significantly, it is not just people who have moved abroad but also Portuguese companies trying to avoid the effects of the crisis, as has occurred with some Irish companies. Estimates for how many Portuguese depart every year for Angola remain hazy, however. The Observatório da Emigração (2014: 36) contends that approximately 10 per cent of Portuguese emigrants moved to Angola 
and Mozambique in 2013, which equates to approximately 12,000. Dos Santos (2013) has noted that the vast majority plan to return to Portugal.

Spaniards speak the same language as much of Latin America. Yet, that region did not experience the same kind of expansion as some of the non-EU countries mentioned above. Many of the major economic powers in the area, such as Mexico, Venezuela and Argentina, have suffered from various degrees of social, political and economic uncertainty. Nevertheless, Latin American countries, such as Ecuador, have attracted considerable numbers of Spanish citizens, but most were actually returnees who acquired Spanish citizenship whilst working in Spain (INE 2014: 11). Emigration to the United States - another destination of choice in the past for all the countries discussed - has become more complicated since September 2001 and that country suffered its own economic problems following the crisis. Consequently, the United States does not feature too prominently in recent emigration flows from the 'PIIGS'.

Many Irish migrants, especially in Australia, succeeded in changing their migration status over time because of their transnational capital. A sizeable proportion of those who first arrived on a working holiday visa, for example, managed to attain long-term skilled visas (known as 457 visas) sponsored by Australian employers, which put them on the path to acquiring permanent residency. Between 2010/11 and 2013/14, over 55,000 Irish came to Australia on initial temporary holiday visas. During the same period, over 32,000 Irish entered the four-year skilled migration scheme. A large number of Irish emigrants were able to transfer to the skilled scheme because they boasted qualifications and experience sought by local employers. In the same period, over 41,000 Italians arrived on working holiday visas but less than 7000 entered the skilled work permit programme.

Emigration debates in the 'PIIGS' have focused largely on the perception that a 'brain drain' is taking place (see, for example, Ortega 2013; Araújo and Ferreira 2013; Labrianidis and Vogiatzis 2013; Tintori and Colucci 2015). No Greek or Portuguese data exists to test these assertions of a 'brain drain'. Nevertheless, Irish, Italian and Spanish figures do suggest that graduates are overrepresented among those leaving by approximately twenty-five per cent in each country (see Figure 5; cf. OECD 2014: 44-5; see also Recchi 2015: 71). While 49 per cent of Irish people aged 25-34 in 2014 held a tertiary qualification of three years or more, 62 per cent of recent Irish emigrants from the same age cohort held the equivalent qualification (Glynn, Kelly and Mac Éinrí 2013: 29; see Ryan in this special section for more details about skilled Irish emigrants in the UK). Irish emigrants were more likely to hold a tertiary qualification than Spanish and, especially, Italian emigrants. This was also a reflection of Ireland's more educated young population. Relatedly, a significant amount of recent Italian and Spanish emigrants had not completed their secondary education, whereas that was the case with only two per cent of Irish emigrants. In some cases, Irish emigrants had left school after their Junior Certificates but had then gone on to complete four-year apprenticeships or various courses that were the equivalent 


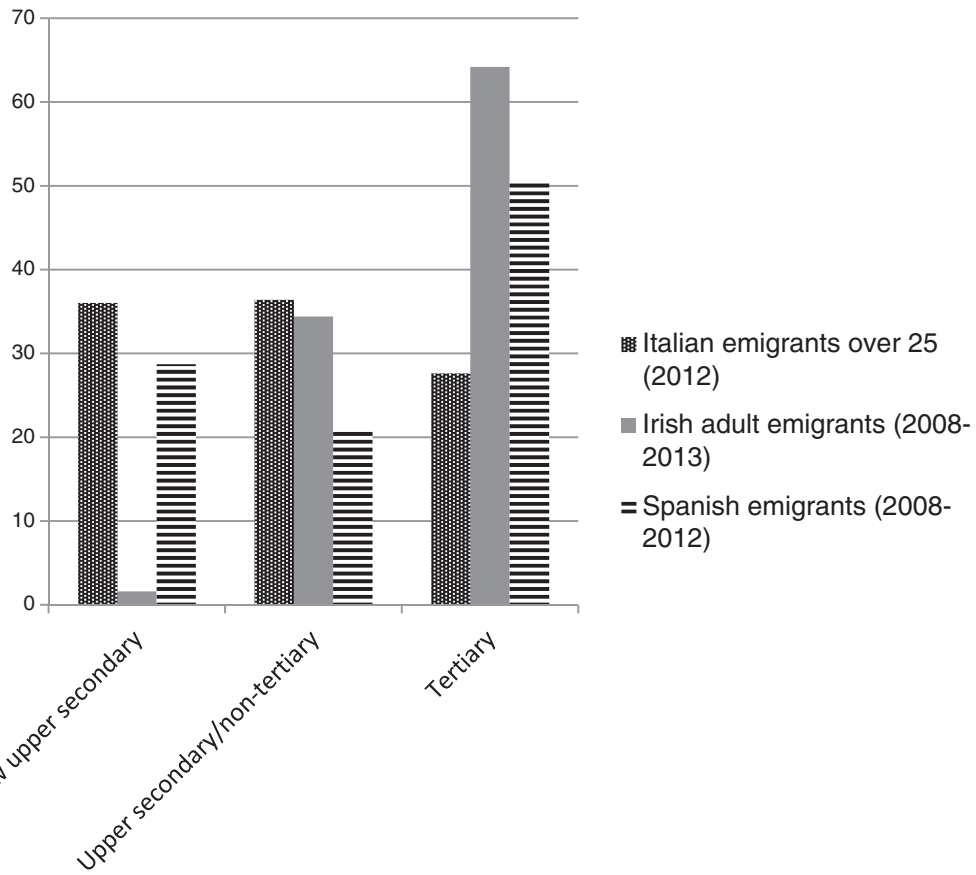

Figure 5 Education levels of Italian, Irish and Spanish emigrants (in per cent). Sources: ISTAT, EMIGRE, Bank of Spain (2015)

of upper secondary education or higher, many of which were coveted in Australia, New Zealand and Canada. Crucially, emigrants felt that their qualifications were generally recognised and respected abroad, as reflected by their satisfaction with their jobs (7.6 out of 10), salaries ( 7.5 out of 10$)$ and career prospects ( 8 out of 10 ), which greatly exceeded their equivalent scores for

Table 1: Top-five destinations for Irish, Italian, Spanish and Portuguese emigrants (2013)

\begin{tabular}{lllll}
\hline & Irish emigrants & Italian emigrants & Spanish emigrants & Portuguese emigrants \\
\hline 1. & UK $^{*}$ & Germany & Ecuador & UK \\
2. & Australia & UK & UK & Switzerland \\
3. & Canada & Switzerland & France & France \\
4. & USA & France & Germany & Germany \\
5. New Zealand & United States & United States & Angola \\
\hline
\end{tabular}

Sources: CSO and destination data, ISTAT, INE, OEM

*Bold denotes language affinity 
their previous employment in Ireland (Glynn, Kelly and Mac Éinrí 2013: 66-7).

Of enormous benefit to Irish emigrants moving to their most popular non-EU destinations was that they spoke the same language, Quebec apart. As Fenoll and Kuehn (2014) note, speaking the language of the host country 'eases migrants' integration and tends to boost their economic success in the country of destination'. Most Irish emigrants departed for English-speaking countries. Emigrants from the 'PIIGS' did not have the same linguistic advantages in their host states as the Irish had, as reflected in Table 1.

One potential reason for explaining why Irish and Portuguese emigrants moved in much greater numbers proportionally than the other 'PIIIGS' relates to their social capital. Irish and Portuguese citizens emigrated in greater numbers per capita in the postwar decades than other 'PIIGS' (the 1950s for the Irish and the late 1960s and early 1970s for the Portuguese). Hundreds of thousands of Irish people again left in the late 1980s and early 1990s. Portugal also experienced its highest levels of emigration for twenty years in the early 1990s (Peixoto 2007: 453), whereas Spanish, Italian and Greek emigration remained minimal during this period.

The unprecedented economic success of the 'Celtic Tiger' years led to many Irish emigrants returning in the late 1990s and 2000s. Sustained economic growth did not mean that Irish people stopped leaving the country, however; it just meant that its character changed. Young Irish people started to take up Australian Working Holiday visas in unprecedented numbers. Most of these people came back to Ireland, but some invariably remained. These soujourners and stayers established Irish communities in specific locations, such as Bondi Junction in Sydney (Collins 2014), which were continually re-greened by regular inflows. A similar pattern emerged in the UK. Despite emigration dropping markedly after the highs of the late 1980s and early 1990s, Irish people continued to move to the UK in the 1990s and 2000s, especially England (see Walter 2008 and Scully in this special section). From 2002 to 2008, approximately 10,000 Irish citizens registered for national insurance numbers in the UK every year (UK Department of Work and Pensions). Some returned while some consistently remained. As occurred in Sydney, Irish networks in London, most notably in Clapham, became more prominent (see Ryan in this special section). The importance of Irish networks abroad is illustrated by the fact that 55 per cent of recent Irish emigrants knew someone in their destination before leaving. Almost a third drew upon Irish contacts to find accommodation and jobs once there (Glynn, Kelly and Mac Éinrí 2013: 60-1).

The vast majority of those leaving Portugal in the 1990s and 2000s were 'temporary' emigrants. In the 1990s, most circulated between Switzerland, Germany and France before returning home (Peixoto 2007: 456). In the 2000s, these trends continued but movement between Portugal and neighbouring Spain became ever more prominent, with over 27,000 moving there in 2007 alone (OEM 2014). With the large-scale closure of factories in Portugal in the 2000s, 
the amount of people migrating to the UK to take up unskilled jobs shunned by locals also increased (Almeida and Corkill 2010: 76). Since the crisis began, the UK has increasingly taken Spain's place as the destination of choice, followed by Switzerland and Germany (OEM 2014). Portuguese emigrants from the 1980s, 1990s and 2000s strengthened Portuguese communities and networks in the UK (Almeida and Corkill 2010) and Switzerland (Peixoto 2007), once more, which presumably aided more recent newcomers. Italian, Greek and Spanish migrants, by contrast, did not leave in similar numbers in these later decades, suggesting that emigrants departing since the crisis did not have regenerated networks to call upon. Of course, large communities of co-citizens still existed, but the age-gap between the new and old waves of migration suggests that it did not have the same dynamic as revitalised Irish and Portuguese networks. Perhaps the recent rejuvenation of Italian, Spanish and Greek networks in Germany, the UK and Switzerland will lead to a rise in future chain migration if conditions do not improve in the 'PIIGS'.

Significantly, 28 per cent of recent Irish emigrants had previous personal experience of having lived abroad for over one year (Glynn, Kelly and Mac Éinrí 2013: 60). People who re-emigrated were able to draw on their previous experience abroad. For those who returned to the same location that they had already lived in, they were able to access earlier established networks. Presumably, this applied to Portuguese workers and nationalised Spaniards who already had extensive experience of migration. As Cairns (2014: 43) has argued, the 'idea of mobility as inherited capital means that such young people are able to make quite pragmatic and relatively well-informed choices'. It would be interesting to explore this hypothesis in more detail in future research.

\section{Intra-EU immobility}

Due to the inability of citizens from Spain, Greece and Italy to migrate to attractive non-EU destinations, most movement from these countries took place within the EU, where European regulations promoted acceptance of education and training qualifications from other member states. Considering the effects the crisis had on youth unemployment in these three countries, and the ease of movement within Europe, it might be expected that large numbers would have left. Yet the lack of intra-EU migration is striking. Why did more people from the 'PIIGS' not move within the EU?

Unlike in the postwar decades, when northern European countries drastically required labour, all European countries have suffered - to varying degrees - as a result of the recent crisis. The crisis hurt many of the traditional destinations that postwar emigrants from Portugal, Italy, Greece and Spain had settled in, such as the Benelux countries and France. The UK and Germany also felt the effects of the downturn. In the UK, unemployment went from slightly above five per cent in 2008 to over eight per cent by the end of 2011, with almost one million 


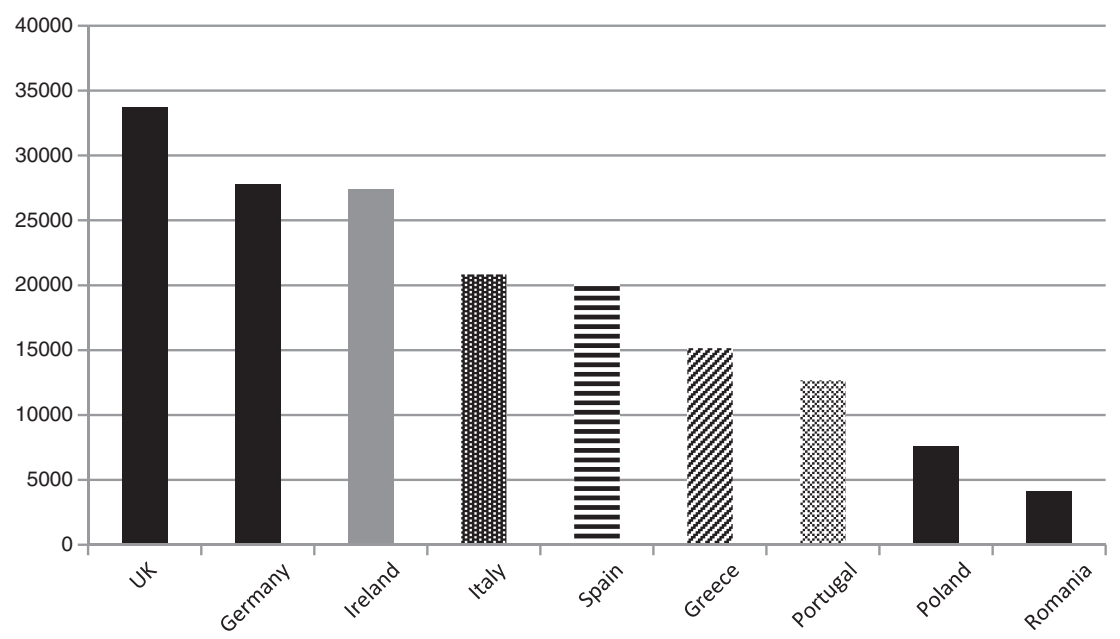

Figure 6 Average annual net wage for single person in Euros, 2014.

Source: Eurostat

people losing their jobs in the interim period. Similarly, German unemployment rose to over eight per cent in late 2008. Switzerland recovered from the crisis before its EU counterparts and consequently became host to an increasing number of Spanish, Italian and, in particular, Portuguese emigrants after the recession. Germany and the UK's economies have since bounced back from the downturn, with unemployment levels now reduced considerably. As a consequence, emigration from the 'PIIGS' has risen. Yet it still pales in size when set against intra-EU movement from the newer EU member states. Poland has a population of less than 40 million, yet it supplied almost as many immigrants to the UK in 2014 as Spain and Italy combined. The German case is even more extreme: more Poles migrated there in 2013 than from all of the 'PIIGS' combined. Similarly, more Romanians moved to Germany in 2013 than Spanish, Italians and Greeks combined (Statistisches Bundesamt 2014).

Moving to Germany, Scandinavia or the UK may be unattractive for citizens from southern Europe because the wages they would earn do not make leaving their family and friends a worthwhile sacrifice. Social welfare benefits have improved considerably in the intervening fifty years in most Western European states. Even in countries that do not have a reliable social welfare system, such as Italy, families often step in to provide support. Also, migrants from the 'PIIGS' might encounter stiff opposition from locals and, more likely, other migrants from non-EU and Eastern European EU migrants if they moved. For Eastern European EU migrants, the wages they can earn in Western Europe are still much greater than what they can accrue at home (see Figure 6).

Therefore, it made sense for these people to move. This might help to explain why Lithuanians and Poles, for example, are still moving in large numbers 
within the EU but Italians, Greeks and Spanish are not. Interestingly, out of all the 'PIIGS', Portuguese wages correspond most closely with those of Eastern European countries, such as Poland, suggesting that the wage differential was large enough to persuade more Portuguese citizens to leave.

\section{Conclusion}

Scholars of Irish emigration have rarely compared Ireland's experience with other European countries. This is partly due to language difficulties that arise when trying to examine a number of case studies but it is also a consequence of an assumption that Irish emigration is exceptional (Lee 1989). By examining contemporary Irish emigration from a comparative perspective, this paper sought to discover whether Ireland's claim of distinctiveness could be verified in relation to current emigration. The findings presented in this paper suggest that Ireland is markedly different when it comes to recent emigration. The destinations that young Irish people selected and their educational profile appeared to starkly contrast with that of emigrants from Greece, Italy and Spain. But if Ireland is not one of the 'PIIGS' when it comes to contemporary emigration, what is it? Some parallels appear to exist with Portugal, but more research is required to examine this in detail. It is clear that because Ireland shared the same language and similar education structures as various non-EU states, such as Australia, New Zealand and Canada, young Irish people had more options to escape the effects of the Great Recession than their southern European counterparts. Perhaps comparing Irish emigration with other English-speaking countries may determine the significance of these old British colonial ties further.

\section{Acknowledgements}

I would like to thank Brian Conway, Mary Hickman and Louise Ryan, as well as the journal's three anonymous reviewers, for their insightful and constructive comments on earlier drafts. This research was supported by a Marie Curie Intra European Fellowship within the 7th European Community Framework Programme.

\section{Note}

1 The pejorative meaning attached to the term 'PIIGS' was clearly demonstrated at the height of the crisis by various cartoons produced in European newspapers and magazines showing a picture of pigs eating from the European trough (e.g. The Sun 2010). The irony is that, as this paper highlights, people in Ireland, Greece, Spain, Portugal and Italy have suffered more hardship since the start of the economic crisis and the subsequent turn to austerity than their Eurozone counterparts. This is demonstrated, in particular, in the rise in unemployment, especially youth unemployment, in these countries and the notable decreases in their annual GDPs. Using the term 'PIIGS' is a classic re-appropriation of the term. As Adam Galinsky et al. (2003: 230) have written, 'For individuals and groups faced with prejudice, 
tackling the negative connotations of group labels may be a means of addressing prejudice itself'. More recently Galinsky et al. (2013: 2020) carried out extensive empirical research on reappropriation and concluded that 'self-labelling with a derogatory label can weaken the label's stigmatizing force'. In addition, 'PIIGS' remains an instantly recognisable term for describing the countries in question; a simple search of Google Scholar shows that the term appeared more than twice as frequently as the less controversial but also less catchy 'GIIPS' in 2014 publications.

\section{References}

Akenson, D.H. 1996. The Irish Diaspora: A Primer. Belfast: Queen's University of Belfast.

Akenson, D.H. 2011. Ireland, Sweden and the Great European Migration, 1815-1914. Liverpool: Liverpool University Press.

Almeida, J.C.P. and D. Corkill. 2010. 'Uma Vida Melhor?: Portuguese migrant workers in a rural community', Immigrants \& Minorities 28(1): 70-85.

Araújo, E. and F. Ferreira. 2013. 'A "Fuga de Cérebros": um discurso multidimensional', pp. 58-82 in E. Araújo, M. Fontes and S. Bento (eds), Para um Debate Sobre Mobilidade e Fuga de Cérebros. Braga: Centro de Estudos de Comunicação e Sociedade.

Australian Department of Immigration and Citizenship. 2014. 'Working holiday visa report', June 2014.

Bank of Spain (M. Izquierdo, J. F. Jimeno, and A. Lacuesta). 2015. 'Spain: from immigration to emigration?', Documentos de Trabajo 1053.

Bauder, H. 2003. "'Brain abuse", or the devaluation of immigrant labour in Canada', Antipode 35(4): 699-717.

Belchem, J. 2011. 'Patterns of mobility: Irish and Polish migration in comparative historical perspective', pp. 3-18 in S. Egger and J. McDonagh (eds), Polish-Irish Encounters in the Old and New Europe. Oxford, Bern: Pieter Lang.

Benson, M. and K. O'Reilly. 2009. 'Migration and the search for a better way of life: a critical exploration of lifestyle migration', The Sociological Review 57(4): 608-25.

Bourdieu, P. 1986. 'The forms of capital', pp. 241-258 in J. Richardson (ed.), Handbook of Theory and Research for the Sociology of Education. New York: Greenswood.

Brettell, C. and J. Hollifield. 2000. 'Migration theory', pp. 1-26 in C. Brettell and J. Hollifield (eds), Migration Theory. London: Routledge.

Cairns, D. 2014. Youth Transitions, International Student Mobility and Spatial Reflexivity: Being Mobile?. Basingstoke: Palgrave Macmillan.

Campbell, M. 2008. Ireland's New Worlds: Immigrants, Politics, and Society in the United States and Australia, 1815-1922. Wisconsin: University of Wisconsin Press.

Collins, P. 2014. 'Website shows suburbs where Irish are living', Irish Echo, http:/www.irishecho.com.au/2014/09/01/where-australias-irish-immigrants-are-living/ 32611, accessed 1 September 2014.

CSO. 2014. 'Population and migration estimates', Dublin: CSO.

Delaney, E. 2000. 'Placing post-war Irish migration to Britain in a comparative European perspective, 1945-1981', pp. 331-56 in A. Bielenberg (ed.), The Irish Diaspora. Harlow: Longman.

Diner, H. 2002. Hungering for America: Italian, Irish and Jewish Foodways in the Age of Mass Migration. Cambridge, MA: Harvard University Press.

Donovan, D. and A. Murphy. 2013. The Fall of the Celtic Tiger: Ireland and the Euro Debt Crisis. Oxford: Oxford University Press. 
dos Santos, Irène. 2013. 'L'émigration au Portugal, avatar d'un pays "semipériphérique", métropole postcoloniale', Hommes et migrations. Revue Française de Référence sur les Dynamiques Migratoires 1302(2): 157-61.

Erel, U. 2010. 'Migrating cultural capital: Bourdieu in migration studies', Sociology 44(4): 642-60.

Fenoll, A.A. and Z. Kuehn. 2014. 'Does foreign language proficiency foster migration of young individuals within the European Union?', IZA Discussion Paper No. 8250.

Fuentes, C.G. et al. 2013. 'From housing bubble to repossessions: Spain compared to other West European countries', Housing Studies 28(8): 1197-217.

Galinsky, A. et al. 2003. 'The reappropriation of stigmatizing labels: implications for social identity', pp. 221-56 in J. Polzer (ed.), Identity Issues in Groups. Bingley, UK: Emerald Group Publishing Limited.

Galinsky, A. et al. 2013. 'The reappropriation of stigmatizing labels: the reciprocal relationship between power and self-labeling', Psychological Science 24(10): 2020-9.

Gerhards, J. and S. Hans. 2013. 'Transnational human capital, education, and social inequality. Analyses of international student exchange', Zeitschrift für Soziologie, 42(2): 99-117.

Gilmartin, M. 2013. 'Changing Ireland, 2000-2012: immigration, emigration and inequality', Irish Geography 46(1-2): 91-111.

Glynn, I. 2011. 'Emigration in the Atlantic: Irish, Italians and Swedes compared (1800-1950)', European History Online/Europäische Geschichte Online, http:// www.ieg-ego.eu/glynni-2011-en

Glynn, I., T. Kelly and P. Mac Éinrí. 2013. Irish Emigration in an Age of Austerity. Cork: University College Cork.

González Ferrer, A. 2013. 'La nueva emigración española. Lo que sabemos y lo que no', Zoom Politico 18: 1-20.

Hatton, T. and J. Williamson. 1998. The Age of Mass Migration: Causes and Economic Impact. New York: Oxford University Press.

Instituto Nacional de Estadística (INE). 2014. 'Population figures at 1 January 2014. Migration statistics 2013', Madrid: INE.

Instituto Nacional de Estatística (INE Portugal). 2014. Estatísticas Demográficas 2013. Lisbon: Instituto Nacional de Estatística.

ISTAT. 2014. 'Indicatori Demografici. Stime per l'anno 2013', June 2014.

Kocka, J. 2003. 'Comparison and beyond', History and Theory 42(1): 39-44.

Krugman, P. 2011. 'The lesser depression', New York Times, 21 July 2011.

Kvamme, A.O.I. 2013. 'Seeking greener pastures: Portuguese emigration to former African colonies', Consultancy Africa Intelligence Discussion Paper.

Labrianidis, L. and Nikos Vogiatzis. 2013. 'Highly skilled migration: what differentiates the "brains" who are drained from those who return in the case of Greece?', Population, Space and Place 19(5): 472-86.

Leahy, A., S. Healy and M. Murphy. 2013. The Impact of the European Crisis. A Study on the Impact of the Crisis and Austerity on People, with a Special Focus on Greece, Ireland, Italy and Spain. Dublin: Social Justice Ireland/Caritas Europa.

Lee, J.J. 1989. Ireland 1912-85. Cambridge: Cambridge University Press.

Lyons, R. 2015. 'East, west, boom and bust: the spread of house prices and rents in Ireland, 2007-12', Journal of Property Research 32(1): 77-101.

Matsaganis, M. and C. Leventi. 2014. 'The distributional impact of austerity and the recession in Southern Europe', South European Society and Politics 19(3): 393-412. 
Meardi, G., A. Martín and M.L. Riera. 2012. 'Constructing uncertainty: unions and migrant labour in construction in Spain and the UK', Journal of Industrial Relations 54(1): 5-21.

Münz, R. 2007. 'Migration, labor markets, and integration of migrants: an overview for Europe', Paper for Hamburg Institute of International Economics (HWWI) Research Programme Migration Research Group.

Observatório da Emigração (OEM). 2014. Emigração Portuguesa Relatório Estatístico 2014. Lisbon: Instituto Universitário de Lisboa.

OECD. 2013. International Migration Outlook 2013. Paris: OECD.

OECD. 2014. Education at a Glance 2014. Paris: OECD.

Ortega, A.S. 2013. 'Fuga de cerebros y crisis en España: los jóvenes en el punto de mira de los discursos empresariales', Revista Internacional de Ciencias Sociales 32: $125-37$.

Peixoto, J. 2007. 'Dinâmicas e regimes migratórios: o caso das migrações internacionais em Portugal', Análise Social 42(183): 445-69.

Piketty, T. 2014. Capital in the Twenty-First Century. London: Belknap.

Portes, A. 1998. 'Social capital: its origins and applications in modern sociology', Annual Review of Sociology 24: 1-24.

Recchi, E. 2015. Mobile Europe: The Theory and Practice of Free Movement in the EU. Basingstoke: Palgrave Macmillan.

RTÉ. 2009. 'Public service recruitment moratorium details', 27 March, http://www.rte. ie/news/2009/0327/115669-economy1/, accessed 8 May 2015.

Ryan, L. 2013. 'Compare and contrast: understanding Irish migration to Britain in a wider context', Irish Studies Review 21(1): 6-19.

Society of Chartered Surveyors Ireland. 2012. The Irish Construction Industry in 2012. Dublin: Society of Chartered Surveyors Ireland.

Statistisches Bundesamt. 2014. 'Bevölkerung und Erwerbstätigkeit Vorläufige Wanderungsergebnisse', Wiesbaden: Statistisches Bundesamt.

Stiglitz, J. 2010. Freefall. Free Markets and the Sinking of the Global Economy. London: Penguin.

The Sun. 2010. 'Cut spending. . .or we'll be PIGS too', 8 February 2010.

Tintori, G. and M. Colucci. 2015. 'Emigration and Italy: a continuing history?', pp. 37-48 in A. Mammone et al. (eds), Routledge Handbook of Contemporary Italy. London: Routledge.

Walter, B. 2008. 'From "flood" to "trickle": Irish migration to Britain 1987-2006', Irish Geography 41(2): 181-94. 